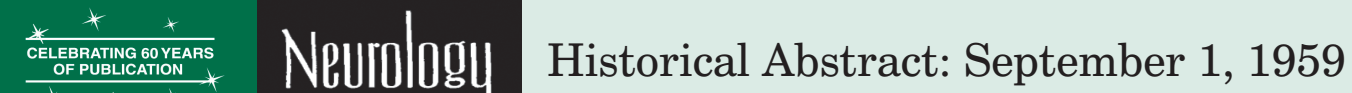 \\ * * *
}

\section{NONINFECTIOUS GRANULOMATOUS ANGIITIS WITH A PREDILECTION FOR THE NERVOUS SYSTEM}

Humberto Cravioto and Irwin Feigin

\section{Neurology 1959;9:599-609}

The central nervous system is only rarely affected in patients with most forms of noninfectious angiitis. In a small proportion of patients with periarteritis nodosa, the vessels of the nervous system alter as do other organs and cause hemorrhage and/or ischemic changes in the brain with neurologic signs and symptoms.

In pulseless disease, temporal arteritis, giant cell arteritis, and thromboangiitis obliterans, the vessels of the nervous system generally escape direct involvement. However, in a few patients, pathologic changes in the great vessels of the neck induce neurologic manifestations which indicate ischemic changes in the brain.

Free Access to this article at www.neurology.org/content/9/9/599

Comment from Steven M. Greenberg, MD, PhD, FAAN, Editorial Board Member: This article was among the first to delineate the entity now generally known as primary angiitis of the central nervous system. This disorder remains difficult to diagnose, leading generations of neurologists to follow scrupulously the authors' suggestion that "this process should be considered among the diagnostic possibilities in those patients in whom a protean neurologic symptomatology does not permit a definite diagnosis of a more common disease." The 50 intervening years have nonetheless seen important gains, particularly in identifying many more secondary triggers of cerebrovascular inflammation as well as some at least partially successful treatments. 


\section{Neurology}

\section{Noninfectious granulomatous angiitis with a predilection for the nervous system}

Humberto Cravioto and Irwin Feigin

Neurology 2011;77;1976

DOI 10.1212/01.wnl.0000408278.62448.d6

\section{This information is current as of November 28, 2011}

\section{Updated Information \&}

Services

Permissions \& Licensing

Reprints including high resolution figures, can be found at:

http://n.neurology.org/content/77/22/1976.citation.full

Information about reproducing this article in parts (figures,tables) or in its entirety can be found online at:

http://www.neurology.org/about/about_the_journal\#permissions

Information about ordering reprints can be found online:

http://n.neurology.org/subscribers/advertise

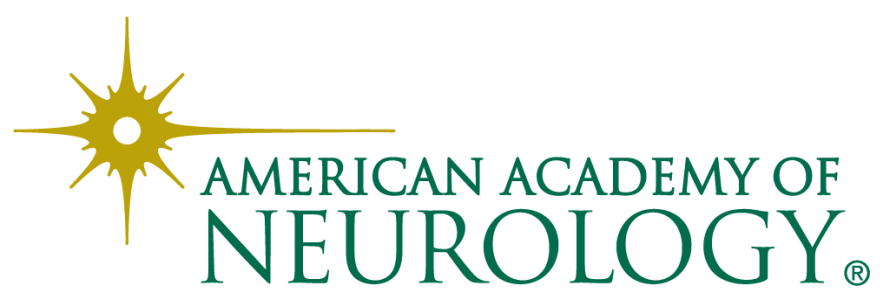

